\title{
FAKTOR YANG BERPENGARUH TERHADAP KOMPETENSI ENTREPRENEUR
}

\author{
Helena Sidharta, Ruswiati Surya Saputra, Noor Azizi B. Ismail \\ e-mail koresponden: helena@ciputra.ac.id
}

\begin{abstract}
Entrepreneurial competence is an important variable that affects the success of an entrepreneur. Factors affecting entrepreneurial competence need to be researched because of strong competence needed by an entrepreneur to achieve success. Based on the literature study, education, entrepreneurial personality and parenting style are indicated to influence entrepreneurial competence. Further studies show that entrepreneurial personality and parenting style require further research because the relationship between these two variables and entrepreneurial competence needs to be understood more deeply. The result of this research is proposition development to further test the relationship between entrepreneurial personality, parenting style, and entrepreneurial competence. Furthermore, based on indicators used in previous studies, testing is suggested using structural equation modeling (SEM) because entrepreneurial personality is measured using Big Five Personality and entrepreneurial competence is measured using indicators from Man \& Lau (2000) so that the indicators of both variables included in the unobserved variable.
\end{abstract}

Keywords:

\section{Pendahuluan}

Kompetensi merupakan salah satu faktor kunci bagi kesuksesan seorang entrepreneur (Obschonka, Silbereisen, Schmitt-Rodermund, \& Stuetzer (2011); Rauch \& Frese (2000)). Kompetensi dibutuhkan oleh entrepreneur untuk membangun bisnisnya dan mempertahankan kesuksesan bisnisnya (Rezaei Zadeh, Hoga, O’Reilly, Cunningham, \& Murphy, 2016). Kemampuan untuk berpikir secara kreatif, inovatif dan cerdik merupakan kompetensi yang penting untuk dimiliki oleh seorang entrepreneur, kompetensi ini membantu seorang individu untuk mengidentifikasi peluang dan memberikan valued added serta kemampuan untuk memprediksi risiko yang akan dihadapinya. Seorang entrepreneur juga diharapkan memiliki kemampuan untuk memotivasi, interpersonal skill, managerial dan leadership. Semua kompetensi tersebut dibutuhkan oleh seorang individu yang memilih berkarier sebagai seorang entrepreneur.
Kompetensi-kompetensi tersebut penting bagi seorang entrepreneur karena seorang entrepreneur harus mampu mengelola bisnisnya baik bisnis baru maupun bisnis yang telah ada dengan terus melihat peluang serta berinovasi. Seorang entrepreneur juga harus mampu mengelola sumber daya yang dimilikinya termasuk networking (Capaldo, Iandoli, \& Ponsiglione, 2004). Pendapat tersebut didukung oleh Rocha \& Birkinshaw (2007) yang menyatakan bahwa entrepreneur merupakan owner sekaligus manager bagi bisnis yang dimilikinya, oleh karenanya kompetensi seorang entrepreneur berbeda dengan manager. Volery, Mueller, \& von Siemens (2013) melakukan studi mengenai perilaku entrepreneur dari enam orang owner-manager dengan melakukan observasi selama 257 jam. Hasil penelitian menunjukkan bahwa seorang owner yang sekaligus berperan sebagai manager dari sebuah perusahaan memiliki kompetensi khusus yang memampukan mereka untuk mengambil berbagai peran dalam bisnisnya. Penelitian ini mendukung 
pernyataan dari Rocha \& Birkinshaw di mana entrepreneur memiliki kompetensi tersendiri, tanpa adanya kompetensi tersebut maka seorang entrepreneur tidak akan mampu untuk mengembangkan bisnisnya. Volery et al. juga mendukung temuan di mana kompetensi memiliki peranan dalam kesuksesan seorang individu untuk menjadi entrepreneur yang sukses, individu yang memiliki entrepreneurial competence mampu membawa kesuksesan bagi bisnis yang didirikannya ataupun yang dipimpinnya.

Indonesia merupakan negara berkembang di mana penduduknya memiliki kemauan untuk membuka atau menjalankan bisnis. Global Entrepreneurship Monitor (GEM) melaporkan bahwa Total Early Entrepreneur Activity (TEA) di Indonesia lebih tinggi dibandingkan China, India, Malaysia, Singapore dan sebagian besar negara di wilayah Asia Pasifik dan Asia Selatan (Amoros \& Bosma, 2014). Level TEA menunjukkan level aktivitas entrepreneurial yang dilakukan oleh para entrepreneur yang melakukan kegiatan entrepreneurial maksimal 3.5 tahun, setelah 3.5 tahun dikenal sebagai established business rate (Global Entrepreneurship Research Association (GERA), 2018). Berdasarkan data GEM di mana Indonesia memiliki level di atas negara tetangga menunjukkan bahwa kegiatan entrepreneurial di Indonesia memang berkembang dengan pesat dibandingkan sebagian besar negara-negara di kawasan Asia Pasifik dan Asia Selatan, namun Improvement level dari TEA di Indonesia masih di bawah negara-negara tetangga contohnya dengan Malaysia dan Singapore. Hubungan antara level TEA dan Level dari aktivitas bisnis yang telah ada cenderung negatif di negara berkembang seperti Indonesia, dikarenakan di negara berkembang alasan seseorang mengembangkan bisnis adalah tidak adanya alternatif lain sehingga mereka mengalami kesulitan dalam menjaga keberlangsungan bisnisnya.
Schutte (2013) menyatakan kesulitan Usaha kecil dan menengah dalam menghadapi tantangan adalah kurangnya dana, kurangnya sumber daya, kurangnya kemampuan formal dan praktis dalam berbisnis, tidak adanya training dan pengalaman yang memadai. Pernyataan Shutte tersebut menunjukkan bahwa usaha kecil dan menengah mengalami kesulitan dikarenakan kurangnya kompetensi untuk berkembang. Kompetensi merupakan kemampuan yang dimiliki oleh seseorang untuk me-manage sumber daya untuk mencapai tujuannya (Obschonka et al., 2011). Bila seorang owner-manager dari bisnis tersebut tidak memiliki kompetensi yang dibutuhkan maka bisnis yang dipimpinnya akan mengalami kesulitan untuk berkembang.

Penelitian terdahulu mengenai kompetensi bagi seorang entrepreneur dan kaitannya dengan kesuksesan mereka dalam mengembangkan bisnis yang dibangunnya memberikan hasil yang menguatkan bahwa kompetensi merupakan faktor yang mampu memprediksi kesuksesan seseorang sebagai seorang entrepreneur (Man \& Lau (2000); Khalid \& Bhatti (2015)). Oleh karenanya penelitian mengenai entrepreneurial competence dan faktor yang mendasarinya merupakan topik yang menarik untuk diteliti lebih lanjut. Dalam model penelitian oleh Sidharta, Ismail, Suryasaputra dan Rahman (2017), kompetensi diusulkan menjadi mediasi dalam model penelitian tersebut untuk mengetahui pengaruh faktor entrepreneurial personality dan parenting style terhadap entrepreneurial success. Namun dalam penelitian tersebut, hubungan antara entrepreneurial personality, parenting style dan entrepreneurial competence masih belum jelas. Memperjelas hubungan antara ketiga variabel tersebut akan memperkuat model penelitian yang diusulkan dan memperjelas peran entrepreneurial competence dalam hubungan antara faktor yang menjadikan seseorang menjadi entrepre- 
neur sukses dengan kesuksesan entrepreneur itu sendiri. Oleh karenanya tujuan dari penelitian ini adalah untuk mengembangkan proposition dari entrepreneurial personality, parenting style dan entrepreneurial competence yang nantinya dapat diujikan untuk memahami pengaruh dari entrepreneurial personality dan parenting style terhadap entrepreneurial competence dan memperkuat model yang diusulkan oleh Sidharta et al. (2017).

\section{LITERATURE REVIEW}

\section{Entrepreneurial Competence}

Khalid \& Bhatti (2015) menyatakan bahwa entrepreneurial competence adalah kapabilitas yang dimiliki oleh seorang individu khususnya kapabilitas untuk membangun inter-firm relations. Menurut Obschonka et.al (2011), entrepreneurial competence adalah kapabilitas untuk memperoleh dan me-manage sumber daya untuk mencapai peluang yang ada pada market tertentu. Berdasarkan pernyataan di atas, entrepreneurial competence merupakan kapabilitas kompleks yang dimiliki oleh seseorang sehingga dia dapat mencapai tujuannya dalam hal ini membangun bisnis baru, mengembangkan pasar baru, prosedur baru dengan tujuan untuk menggapai tujuannya. Kapabilitas yang dimiliki oleh seorang entrepreneur menjadikan dirinya memiliki kemampuan untuk melihat peluang, mengembangkannya dan memanfaatkan sumber daya yang dimilikinya untuk mencapai tujuan. Mitchelmore \& Rowley (2010) menyatakan pentingnya entrepreneurial competence bagi perkembangan start up business di mana seorang entrepreneur harus mampu menerjemahkan apa yang dipercayainya, nilai-nilai dan budaya yang dibawanya saat membangun bisnis, kemampuan memperoleh dan me-manage sumber daya, serta berkomunikasi dan berhubungan dengan orang lain. Berdasarkan pernyataan tersebut, entrepreneurial competence penting bagi seseorang yang memutuskan untuk memilih menjadi entrepreneur. Man \& Lau (2000); Man, Lau, \& Snape (2008) dan Ahmad, Ramayah, Wilson, \& Kummerow (2015) menguatkan pentingnya entrepreneurial competence dalam memprediksi entrepreneurial success.

Dalam mengembangkan entrepreneurial competence, penelitian terdahulu opportunity competencies, relationship competencies, conceptual competencies, organizing competencies, strategic competencies dan commitment competencies banyak digunakan sebagai variable yang mampu memengaruhi entrepreneurial competencies (Man \& Lau (2000); Man et al. (2008)), di mana kompetensi-kompetensi di atas menjadi indikator dalam mengukur entrepreneurial competence. Baum \& Locke (2004) mengembangkan penelitian mengenai hubungan antara entrepreneurial personality traits terhadap skill dari entrepreneur dan hubungannya terhadap kinerjanya, hasil dari penelitian menunjukkan bahwa entrepreneurial personality traits memiliki pengaruh terhadap pengembangan skill dari individu yang secara tidak langsung turut memengaruhi kinerjanya. Skill merupakan bagian dari kompetensi yang diharapkan dimiliki oleh individu.

Berdasarkan Tabel 1, entrepreneur education memiliki pengaruh dalam perkembangan entrepreneurial competencies. Melalui pendidikan, kompetensi dapat dikembangkan. Hasil dari penelitian yang telah dilakukan menunjukkan bahwa dengan adanya pendidikan melalui training maka kompetensi siswa meningkat. Oleh karenanya, entrepreneurship education terbukti mampu memprediksi entrepreneurial competence. Berdasarkan tabel 1 yang merupakan 
Tabel 1 Hasil Penelitian Mengenai Entrepreneurial Competence

\begin{tabular}{|c|c|c|c|}
\hline No. & Peneliti & $\begin{array}{l}\text { Variable yang Memprediksi } \\
\text { Entrepreneurial Competence }\end{array}$ & Hasil \\
\hline 1 & $\begin{array}{l}\text { Schmitt-Rodermund } \\
\text { (2004) }\end{array}$ & $\begin{array}{l}\text { Entrepreneurial Personality } \\
\text { Authoritative Parenting Style }\end{array}$ & $\begin{array}{l}\text { Dalam penelitian ini terbukti bahwa } \\
\text { early entrepreneurial competence dipe- } \\
\text { ngaruhi oleh entrepreneurial personal- } \\
\text { ity dan authoritative parenting style. } \\
\text { Rasmussen et.al (s011) menyatakan } \\
\text { bahwa kompetensi berkembang seirin } \\
\text { perkembangan individu, sehingga } \\
\text { diprediksi entrepreneurial personality } \\
\text { dan authoritative parenting style ber- } \\
\text { pengaruh juga terhadap entrepre- } \\
\text { neurial competence bagi individu yang } \\
\text { menjalankan start up business. }\end{array}$ \\
\hline 2 & Sanchez (2013) & Entrepreneurship education & $\begin{array}{l}\text { Entrepreneurship Education berpenga- } \\
\text { ruh terhadap peningkatan entrepre- } \\
\text { neurial competencies setelah siswa } \\
\text { mengikuti training entrepreneurship. }\end{array}$ \\
\hline 3 & $\begin{array}{l}\text { Volery, Mueller \& von } \\
\text { Siemens (2013) }\end{array}$ & Entrepreneurship education & $\begin{array}{l}\text { Entrepreneurship Education berpe- } \\
\text { ngaruh terhadap peningkatan entre- } \\
\text { preneurial competencies setelah siswa } \\
\text { mengikuti training entrepreneurship. }\end{array}$ \\
\hline 4 & $\begin{array}{l}\text { Mitchelmore \& Rowley } \\
\text { (2010) }\end{array}$ & $\begin{array}{l}\text { Person' background (personal- } \\
\text { ity, social role, self-image) } \\
\text { Training and education }\end{array}$ & $\begin{array}{l}\text { Dalam penelitian ini ditemukan bahw: } \\
\text { entrepreneurial competence erat kait- } \\
\text { annya dengan latar belakang seseoran } \\
\text { termasuk dengan personality-nya seba- } \\
\text { gai seorang individu. Social role juga } \\
\text { memiliki pengaruh dalam perkem- } \\
\text { bangan kompetensi. Adanya training } \\
\text { dan education membantu mengem- } \\
\text { bangkan entrepreneurial competence. }\end{array}$ \\
\hline 5 & Baum \& Locke (2004) & Personality Traits & $\begin{array}{l}\text { Dalam penelitian ini terbukti bahwa } \\
\text { personality trait berpengaruh terhadar } \\
\text { pengembangan skill yang dibutuhkan } \\
\text { oleh entrepreneur. Skill merupakan } \\
\text { bagian dari kompetensi sehingga dapa } \\
\text { diindikasikan bahwa personality trait } \\
\text { turut berpengaruh terhadap entrepre- } \\
\text { neurial competence. }\end{array}$ \\
\hline 6 & Obschonka et.al. (2012) & $\begin{array}{l}\text { Entrepreneurial Big Five } \\
\text { Personality }\end{array}$ & $\begin{array}{l}\text { Hasil penelitian ini menguatkan duga- } \\
\text { an bahwa Big Five Personality mampu } \\
\text { memprediksi early entrepreneurial } \\
\text { competence. Hasil ini sesuai dengan } \\
\text { penelitian Schmitt-Rodermund (2004) } \\
\text { dan menunjukkan bahwa ada indikasi } \\
\text { entrepreneurial personality yang dije- } \\
\text { laskan menggunakan Big Five Per- } \\
\text { sonality Traits memengaruhi entrepre- } \\
\text { neurial competence. }\end{array}$ \\
\hline
\end{tabular}




\begin{tabular}{|c|c|c|c|}
\hline 7 & $\begin{array}{l}\text { Scherer, Adams, Carley, } \\
\text { \& Wiebe (1989) }\end{array}$ & $\begin{array}{l}\text { Parent Entrepreneurial Role } \\
\text { Model }\end{array}$ & $\begin{array}{l}\text { Hasil penelitian menunjukkan parent } \\
\text { entrepreneurial role model turut serta } \\
\text { dalam memengaruhi pendidikan dan } \\
\text { training yang diikuti oleh putra/putri- } \\
\text { nya yang tentunya berperan tidak } \\
\text { langsung dalam entrepreneurial com- } \\
\text { petence }\end{array}$ \\
\hline 8 & Boz \& Ergeneli (2014) & $\begin{array}{l}\text { Entrepreneurial Personality } \\
\text { Parenting Style }\end{array}$ & $\begin{array}{l}\text { Hasil penelitian menunjukkan bahwa } \\
\text { Parenting style seorang ayah berperan } \\
\text { dalam mengembangkan kemampuan } \\
\text { entrepreneur dari anaknya. Personality } \\
\text { dari individu turut berperan, bagi } \\
\text { seorang yang memiliki score tinggi di } \\
\text { extraversion dan openness to expe- } \\
\text { rience, di mana individu tersebut cen- } \\
\text { derung menjadi entrepreneur. }\end{array}$ \\
\hline
\end{tabular}

tabel hasil penelitian studi literatur yang dilakukan berkaitan dengan variabel yang turut memprediksi entrepreneurial competence, yang menarik adalah adanya pengaruh dari personality terhadap early entrepreneurial competencies, sehingga ada dugaan bahwa personality dapat memengaruhi entrepreneurial competence pada owner dari start up business. Variabel lain yang menarik adalah adanya peran dari orang tua. Schmitt Rodermund (2004), menemukan bahwa authoritative parenting style berpengaruh terhadap early entrepreneurial competence. Mitchelmore \& Rowley (2010) dan Scherer, Adam, Carley \& Wiebe (1989) menemukan adanya role model yang mampu membantu perkembangan kompetensi yang dimiliki seorang entrepreneur. Role model yang pertama bagi seorang anak adalah orang tua, Boz \& Ergeneli (2014) menyatakan bahwa parenting style ayah berperan dalam mengembangkan kemampuan entrepreneur dari anaknya. Penelitian-penelitian tersebut membentuk dugaan bahwa parenting style turut serta memengaruhi entrepreneurial competence bagi seorang entrepreneur. Berdasarkan studi literature mengenai variable yang turut memengaruhi entrepreneurial competence di mana per- sonality dan parenting style diduga terindikasi memengaruhi entrepreneurial competence namun membutuhkan studi lebih lanjut, maka penelitian lebih lanjut mengenai hubungan variabel-variabel ini patut untuk dikembangkan.

\section{PEMBANGUNAN FRAMEWORK}

\section{Entrepreneurial Personality dan Entrepreneur- ial Competence}

Volery, Mueller, \& von Siemens (2013) menemukan bahwa seorang entrepreneur mampu menjalankan aktivitas entrepreneurship-nya didukung oleh dirinya sendiri. Dalam penelitian tersebut, entrepreneur yang memiliki kemampuan untuk memilih aksinya seperti pengambilan risiko, melihat dari berbagai perspektif, pada dasarnya dipengaruhi oleh dirinya sendiri. Berdasarkan penelitian tersebut untuk memiliki entrepreneurial competencies dipengaruhi oleh diri entrepreneur itu sendiri. Entrepreneurial personality merupakan bagian dari diri seorang entrepreneur oleh karenanya entrepreneurial personality seharusnya mampu memengaruhi kemampuan entrepreneurial seseorang. 


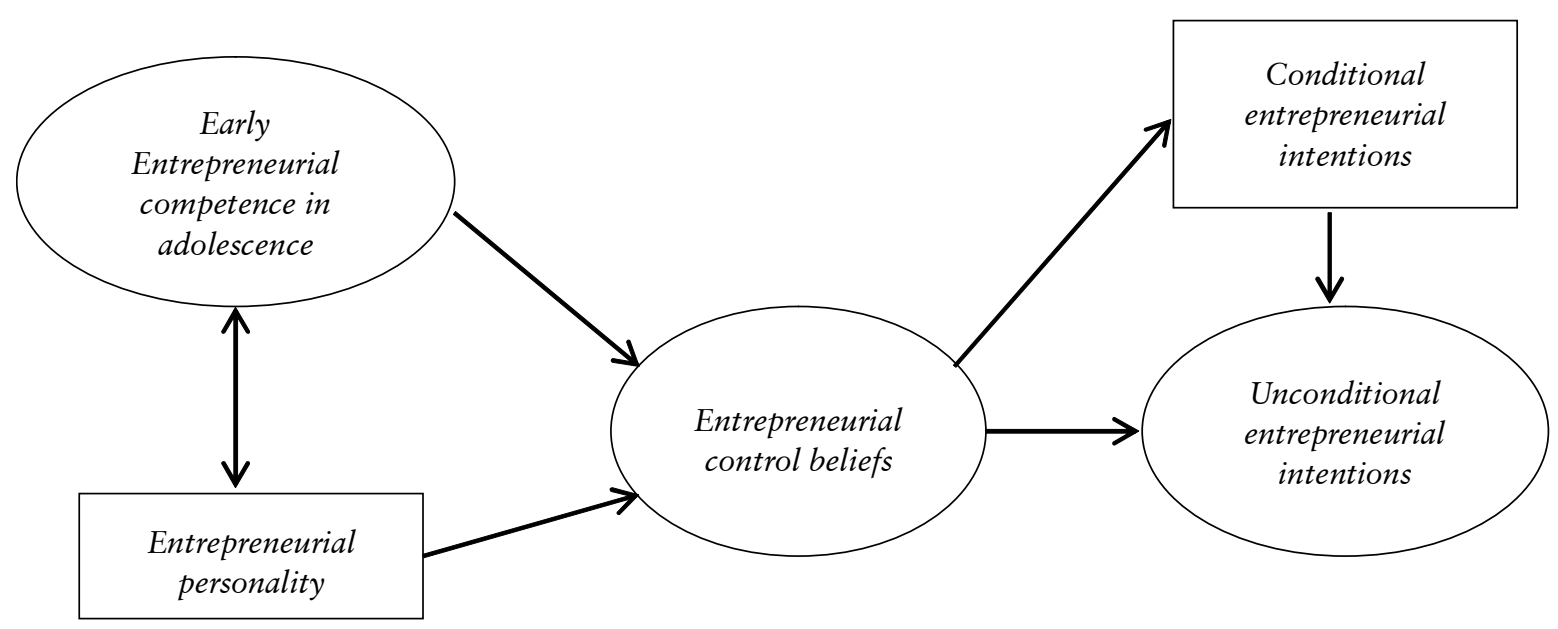

Gambar 1 Mediation Model Obschonka et al.

Sumber: Obschonka, Silbereisen, \& Schmitt-Rodermund (2010)

Obschonka et.al (2010) menguji variabel yang memprediksi entrepreneurial intentions, dalam model yang diujinya, entrepreneurial personality dan early entrepreneurial competence pada masa remaja saling memengaruhi satu variabel dengan variabel yang lain dan bersama-sama memengaruhi entrepreneurial intention dari respondennya. Dari penelitian ini terlihat bahwa entrepreneurial personality memang berpengaruh terhadap pilihan seseorang menjadi entrepreneur dan menunjukkan bahwa entrepreneurial personality dapat memengaruhi kompetensi seorang remaja. Lebih lanjut, Obschonka et al. (2011) mengembangkan penelitian yang hasilnya menunjukkan bahwa early entrepreneurial competence mendukung kemampuan seorang entrepreneur untuk berpikir dan bertindak, di mana bagi seorang entrepreneur kemampuan itu adalah entrepreneurial competence. Berdasarkan kedua penelitian tersebut, entrepreneurial personality dan early entrepreneurial competence memiliki hubungan di mana entrepreneurial personality terbukti mampu memprediksi early entrepreneurial competence. Schmitt-Rodermund (2004) mendukung temuan tersebut di mana dalam penelitiannya, entrepreneurial personality mampu memengaruhi early entrepreneurial competence yang dimiliki oleh adult entrepreneur pada masa remaja. Rasmussen, Mosey, \& Wright (2011) mengemukakan dalam penelitiannya, kompetensi dalam diri individu akan berkembang selama individu berkembang, oleh karenanya early entrepreneurial competence dalam diri remaja akan menjadi entrepreneurial competence saat dewasa atau saat dia mulai menjalankan aktivitas entrepreneurial-ya. Berdasarkan indikasi tersebut, entrepreneurial personality seharusnya mampu memprediksi entrepreneurial competence dikarenakan dari penelitian yang telah ada entrepreneurial personality memiliki pengaruh terhadap early entrepreneurial competence.

Brandstatter (2011) membangun analisisnya dari theory of action yang dikemukakan oleh Frese \& Zapf (1994) di mana personality mampu memprediksi kesuksesan seorang entrepreneur dengan dimediasi oleh karakteristik seperti memiliki visi dan tujuan, strategi dan action plan, effectuation, experimentation dan innovation, kemampuan berkomunikasi, serta kemampuan untuk belajar. Gambar 2 menggambarkan model yang dikembangkan Frese (2009) yang dijadikan dasar dalam penelitian Brandstatter. 


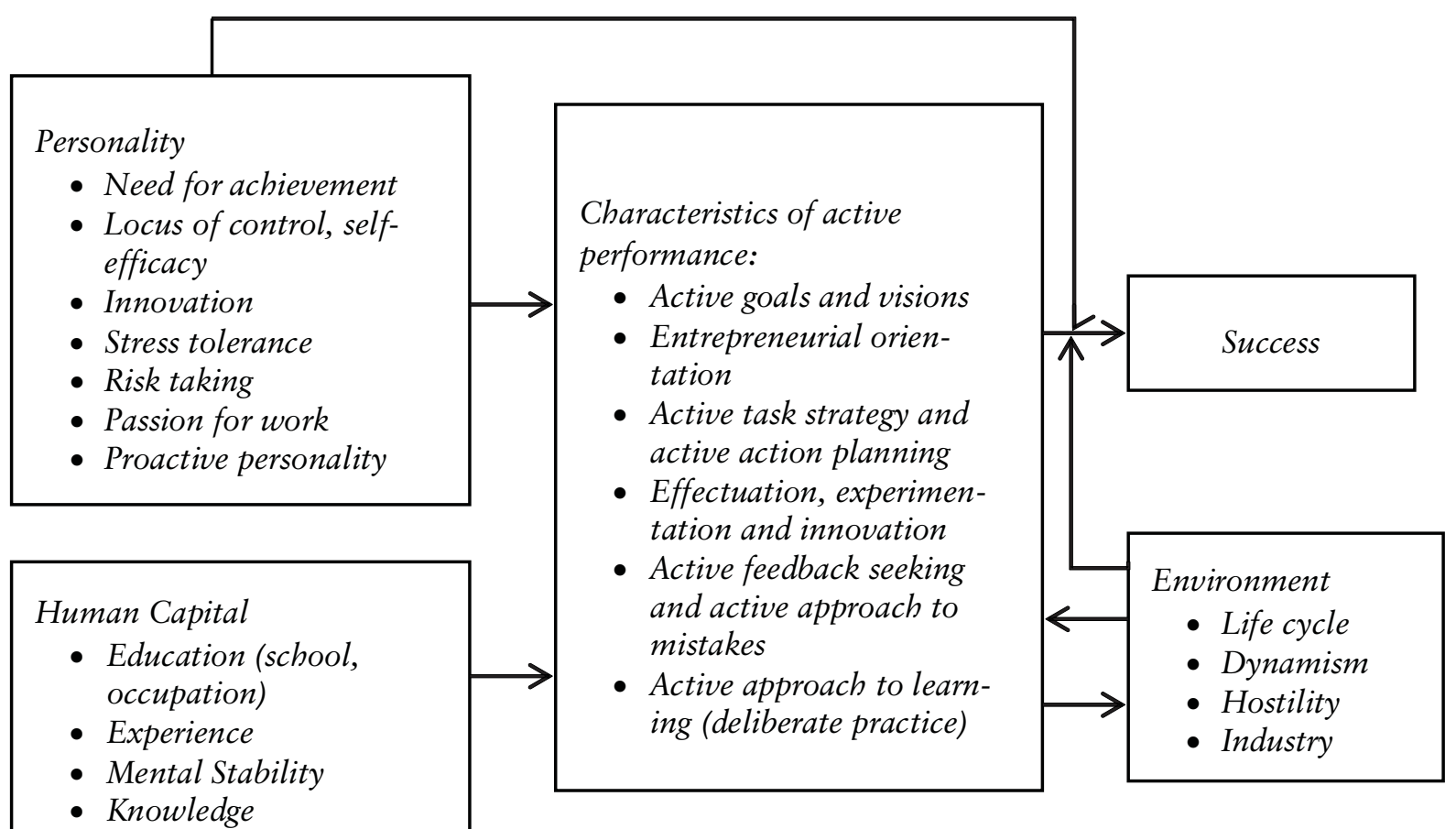

Gambar 2 Complex Process Model of Entrepreneurship by Frese (2009)

Sumber: Brandstatter (2011)

Pada Gambar 2 terlihat terdapat karakteristik yang diusulkan menjadi variabel mediasi antara personality dan success. Karakteristik tersebut bila dibandingkan dengan indikator dari entrepreneurial competence yang diusulkan oleh Man \& Lau (2000) memiliki kesamaan. Berikut pada Tabel 2 di bawah ini indikator entrepreneurial competence oleh Man \& Lau (2000).

Tabel 2 Indikator Entrepreneurial Competence

\begin{tabular}{|c|c|c|}
\hline $\begin{array}{c}\text { Competency } \\
\text { Area } \\
\end{array}$ & Behavioral Focus & Item dalam area \\
\hline $\begin{array}{l}\text { Opportunity } \\
\text { competencies }\end{array}$ & $\begin{array}{l}\text { Kompetensi yang berhu- } \\
\text { bungan dengan mengenali } \\
\text { market opportunities }\end{array}$ & $\begin{array}{l}\text { - Mengidentifikasi } \\
\text { - Menilai } \\
\text { - Mencari } \\
\end{array}$ \\
\hline $\begin{array}{l}\text { Relationship } \\
\text { competencies }\end{array}$ & $\begin{array}{l}\text { Kompetensi yang berhu- } \\
\text { bungan dengan hubungan } \\
\text { antar-individu ataupun } \\
\text { individu dengan grup }\end{array}$ & $\begin{array}{l}\text { - Membangun dan menjaga network dan relationship yang dimi- } \\
\text { liki } \\
\text { - Memanfaatkan network dan relationship yang dimiliki } \\
\text { - Membangun dan menjaga kepercayaan dari partner bisnis dan } \\
\text { karyawan } \\
\text { - Memanfaatkan kepercayaan untuk mengembangkan bisnis } \\
\text { - Memperkenalkan diri secara efektif membangun citra profe- } \\
\text { - Kional } \\
\text { - Nomunikasi } \\
\text { - Manosiasi } \\
\text { - Membangun kesepakatan bersama }\end{array}$ \\
\hline
\end{tabular}




\begin{tabular}{|c|c|c|}
\hline $\begin{array}{l}\text { Conceptual } \\
\text { competencies }\end{array}$ & $\begin{array}{l}\text { Kompetensi yang berhu- } \\
\text { bungan dengan kemampuan } \\
\text { konseptual yang tecermin } \\
\text { dalam perilaku seorang } \\
\text { entrepreneur }\end{array}$ & $\begin{array}{l}\text { - Berpikir secara intuitif } \\
\text { - Melihat dari berbagai sudut pandang yang berbeda } \\
\text { - Innovative } \\
\text { - Mampu menilai risiko }\end{array}$ \\
\hline $\begin{array}{l}\text { Organizing } \\
\text { competencies }\end{array}$ & $\begin{array}{l}\text { Kompetensi yang berhu- } \\
\text { bungan dengan kemampuan } \\
\text { me-manage sumber daya } \\
\text { yang terdapat dalam organi- } \\
\text { sasi }\end{array}$ & $\begin{array}{l}\text { - Mampu membuat perencanaan } \\
\text { - Mampu mengorganisasi } \\
\text { - Kemampuan memimpin } \\
\text { - Kemampuan memotivasi } \\
\text { - Kemampuan mendelegasi } \\
\text { - Kemampuan untuk melakukan kontrol }\end{array}$ \\
\hline $\begin{array}{l}\text { Strategic } \\
\text { competencies }\end{array}$ & $\begin{array}{l}\text { Kompetensi yang berhu- } \\
\text { bungan dengan memfor- } \\
\text { mulasi, mengevaluasi dan } \\
\text { mengimplementasikan } \\
\text { strategi dalam perusahaan }\end{array}$ & $\begin{array}{l}\text { - Memiliki visi } \\
\text { - Menyusun dan mengevaluasi tujuan } \\
\text { - Me-manage kapabilitas yang dimiliki } \\
\text { - Membuat strategi yang mampu merespons perubahan } \\
\text { - Menyusun dan mengevaluasi posisi perusahaan } \\
\text { - Bergerak maju untuk menetapkan tujuan } \\
\text { - Menggunakan taktik } \\
\text { - Menyusun budget untuk implementasi strategi } \\
\text { - Mengontrol hasil dari strategi yang diterapkan }\end{array}$ \\
\hline $\begin{array}{l}\text { Commitment } \\
\text { competencies }\end{array}$ & $\begin{array}{l}\text { Kompetensi yang mendo- } \\
\text { rong seorang entrepreneur } \\
\text { untuk menjalankan bisnis }\end{array}$ & $\begin{array}{l}\text { - Mempertahankan usaha } \\
\text { - Memiliki komitmen jangka panjang } \\
\text { - Dedikasi kepada pekerjaan } \\
\text { - Memiliki komitmen terhadap karyawan } \\
\text { - Memiliki komitmen terhadap kepercayaan dan nilai-nilai awal } \\
\text { - Memiliki komitmen terhadap tujuan diri sendiri } \\
\text { - Tidak mudah putus asa }\end{array}$ \\
\hline $\begin{array}{l}\text { Supporting } \\
\text { competencies }\end{array}$ & $\begin{array}{l}\text { Kompetensi yang mendu- } \\
\text { kung seorang individu } \\
\text { untuk menjadi entrepreneur. }\end{array}$ & $\begin{array}{l}\text { - Belajar dari pengalaman masa lampau, kesalahan maupun dari } \\
\text { individu lain } \\
\text { - Beradaptasi dengan pengalaman baik diri sendiri maupun orang } \\
\text { lain baik langsung maupun tidak langsung berkaitan dengan diri } \\
\text { maupun organisasinya } \\
\text { - Me-manage waktu } \\
\text { - Mengevaluasi diri sendiri } \\
\text { - Memiliki kehidupan yang seimbang antara pekerjaan dan sosial } \\
\text { - Me-manage stres } \\
\text { - Memiliki integritas }\end{array}$ \\
\hline
\end{tabular}

Sumber: Man \& Lau (2000)

Berdasarkan Gambar 2 dan Tabel 2 dapat dilihat bahwa karakteristik dalam Gambar 2 pada dasarnya sesuai dengan indikator entrepreneurial competence yang terdapat pada Tabel 2 . Pada Tabel 3 di bawah ini dapat dilihat kesesuaian dari karakteristik dalam model yang dipropose oleh Frese dan diadaptasi oleh Branstatter (2011) dengan indikator entrepreneurial competence oleh Man \& Lau (2000).

Berdasarkan Tabel 3, terlihat bahwa karakteristik yang diadaptasi oleh Brandstatter (2011) sesuai dengan indikator entrepreneurial competence oleh Man \& Lau (2000), oleh karenanya dapat disimpulkan bahwa personality memiliki pengaruh terhadap entrepreneurial competence tidak hanya terhadap early entrepreneurial competencies. Perbandingan pada Tabel 3 menguatkan indikasi yang dibangun dengan melihat hasil penelitian dari Schmitt-Rodermund (2004), Obschonka et al. (2010) dan Rasmussen et al. (2011). 
Tabel 3 Perbandingan Karakteristik dalam Model Penelitian Frese dan Indikator Entrepreneurial Competence

\begin{tabular}{|c|c|c|}
\hline $\begin{array}{c}\text { Karakteristik dalam } \\
\text { Model Penelitian Frese }\end{array}$ & $\begin{array}{c}\text { Indikator } \\
\text { Entrepreneurial } \\
\text { Competence Man \& Lau }\end{array}$ & Keterangan \\
\hline Active goals and visions & Strategic competencies & $\begin{array}{l}\text { Karakteristik di mana individu aktif dalam me- } \\
\text { nyusun goals (tujuan) dan visi sesuai dengan } \\
\text { kompetensi dalam area strategic yang } \\
\text { diusulkan oleh Man \& Lau yaitu memiliki visi, } \\
\text { mampu menyusun dan mengevaluasi tujuan, } \\
\text { bergerak maju dalam menetapkan tujuan ke } \\
\text { depan. }\end{array}$ \\
\hline $\begin{array}{l}\text { Active task strategy and } \\
\text { active action planning }\end{array}$ & $\begin{array}{l}\text { Organizing competencies } \\
\text { Strategic competencies }\end{array}$ & $\begin{array}{l}\text { Karakteristik di mana individu aktif dalam } \\
\text { membangun strategi sesuai dengan strategic } \\
\text { competencies yang merupakan indikator dari } \\
\text { entrepreneurial competence, sementara itu, } \\
\text { dalam indikator organizing competencies } \\
\text { terlihat kompetensi yang dimiliki oleh } \\
\text { entrepreneur meliputi kemampuan } \\
\text { merencanakan, mengorganisasi, memimpin } \\
\text { hingga mengontrol. Penjelasan indikator } \\
\text { organizing competencies ini sesuai dengan } \\
\text { active action planning dari karakteristik di } \\
\text { model yang diusulkan Frese. }\end{array}$ \\
\hline $\begin{array}{l}\text { Effectuation, } \\
\text { experimentation and } \\
\text { innovation }\end{array}$ & $\begin{array}{l}\text { Relationship } \\
\text { competencies } \\
\text { Conceptual competencies }\end{array}$ & $\begin{array}{l}\text { Dalam relationship competencies dijelaskan } \\
\text { pentingnya memanfaatkan network dan } \\
\text { relationship yang dimiliki, tidak hanya } \\
\text { membangun network dan relationship saja. } \\
\text { Effectuation pada dasarnya memanfaatkan } \\
\text { network yang dimiliki dalam membangun } \\
\text { bisnis, sehingga sesuai dengan indikator } \\
\text { entrepreneurial competence. Dalam conceptual } \\
\text { competencies ditekankan kemampuan inovasi } \\
\text { dan mencari solusi dari berbagai sudut } \\
\text { pandang yang berbeda, sesuai dengan karak- } \\
\text { teristik experimentation dan innovation. }\end{array}$ \\
\hline $\begin{array}{l}\text { Active social strategy for } \\
\text { networking }\end{array}$ & $\begin{array}{l}\text { Relationship } \\
\text { competencies }\end{array}$ & $\begin{array}{l}\text { Active social strategy for networking yang } \\
\text { dimaksud adalah membangun strategi melalui } \\
\text { sosialisasi yang terencana. Dalam relationship } \\
\text { competencies dijabarkan selain membangun, } \\
\text { mampu berkomunikasi, bernegosiasi, serta me- } \\
\text { manage konflik sehingga pemahaman untuk } \\
\text { membangun network yang terencana sesuai } \\
\text { dengan penjabaran dari kompetensi ini. }\end{array}$ \\
\hline $\begin{array}{l}\text { Active feedback seeking } \\
\text { and active approach to } \\
\text { mistakes }\end{array}$ & Supporting competencies & \multirow{2}{*}{$\begin{array}{l}\text { Dalam supporting competencies, kemampuan } \\
\text { untuk belajar terus menerus, kemampuan } \\
\text { refleksi terhadap diri sendiri merupakan } \\
\text { ukuran dari kompetensi ini. Ukuran ini sesuai } \\
\text { dengan karakteristik dalam model Frese di } \\
\text { mana mampu menerima feedback, mencari dan } \\
\text { mengakui kesalahan serta aktif untuk belajar. }\end{array}$} \\
\hline $\begin{array}{l}\text { Active approach to } \\
\text { learning }\end{array}$ & Supporting competencies & \\
\hline
\end{tabular}

Sumber: Brandstatter (2011); Man \& Lau (2000) 
Authoritative Parenting Style dan Entrepreneurial Competence

Pada tahun 1971, Baumrind mengemukakan bahwa terdapat tiga parenting style yang dilakukan oleh orang tua dalam membesarkan putra/ putrinya. Dua belas tahun kemudian, Maccoby dan Martin menambahkan satu parenting style lagi, sehingga terdapat empat parenting style yaitu authoritarian, permissive, authoritative dan neglectful. Keempat parenting style tersebut merupakan kombinasi dari responsiveness dan demandingness (Garcia \& Gracia, 2009). Parenting style berperan dalam pembentukan karakter, pengendalian diri, moral dan perilaku (Papalia, Olds, \& Feldman, 2003), di mana hasilnya berpengaruh terhadap kemampuan anak tersebut (Shute, Hansen, Underwood, \& Razzouk, 2011). Berdasarkan penelitian berkaitan dengan kemampuan akademik seorang anak, authoritative parenting style dan indulgent parenting style merupakan dua tipe parenting style yang menunjukkan hasil positif terhadap kemampuan akademik (Garcia \& Gracia (2009); Shute, Hansen, Underwood, \& Razzouk (2011)). Penelitian oleh
Sovet \& Metz (2014) menunjukkan hasil yang sedikit berbeda. Hasil penelitian ini menunjukkan bahwa authoritative parenting style dan authoritarian parenting style-lah yang berperan dalam pengembangan kemampuan seorang anak. Ishak, Suet, \& Poh (2012) menekankan bahwa authoritative dan authoritarian merupakan dua tipe parenting style yang paling banyak digunakan. Hasil dari penelitian ini menunjukkan bahwa authoritative parenting style lebih memberikan hasil positif daripada authoritarian parenting style.

Berdasarkan Gambar 3, Authoritative parenting style merupakan parenting style di mana orang tua responsive terhadap kebutuhan anaknya sekaligus membangun garis batas apa yang anaknya boleh lakukan. Indulgent parenting style di sisi lain menunjukkan bahwa orang tua responsive terhadap kebutuhan anaknya namun tidak memberi batasan bagi anaknya. Authoritarian parenting style kebalikan dari indulgent parenting style, di tipe ini, orang tua cenderung memberikan batasan terhadap anaknya dan tidak responsive terhadap kebutuhan anaknya. Berda-

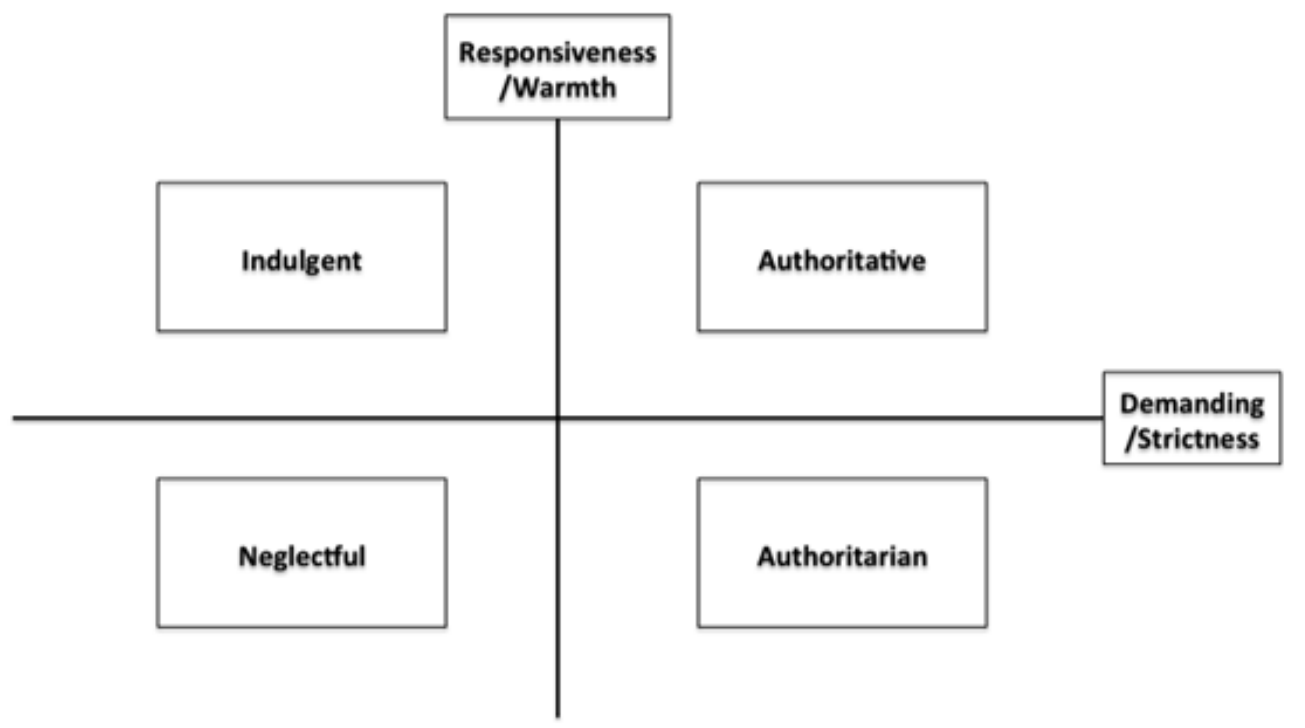

Gambar 3 Four Typology Model of Parental Style Sumber: Garcia \& Gracia (2009) 
sarkan hasil penelitian berkaitan dengan kemampuan akademik, disimpulkan bahwa responsive adalah kunci sukses orang tua dalam mengembangkan karakter dan kompetensi anaknya termasuk dalam pemilihan karier anaknya khususnya orang tua dengan tipe authoritative parenting style (Ishak et al., 2012).

Berkaitan dengan entrepreneurship, Jiang, Hayward, \& Morris (2017) menyatakan bahwa seorang anak yang tumbuh dalam keluarga yang memiliki bisnis belum tentu menjadi entrepreneur kecuali bila anak tersebut diberi kesempatan untuk dekat dan memahami bisnis keluarganya. Pendekatan orang tua dalam parenting style turut membangun lingkungan yang membantu anak untuk memiliki kesempatan menjadi entrepreneur. Dalam penelitian ini, authoritative parenting style merupakan parenting style yang diusulkan dalam membentuk entrepreneurial behavior bagi seorang anak. Penelitian ini juga didukung oleh penelitian Schmitt-Rodermund (2004) dan Boz \& Ergeneli (2014) di mana dalam penelitian tersebut, Schmitt Rodermund secara eksplisit menguji authoritative parenting style dan entrepreneurial success dengan early entrepreneurial competence sebagai variabel mediasi, sedangkan Boz \& Ergeneli menyimpulkan dalam penelitiannya bahwa seorang anak yang orang tuanya lebih mampu menerima dan tidak selalu mengontrol anaknya lebih memiliki entrepreneurial karakteristik. Berdasarkan penelitian-penelitian tersebut, authorative parenting style mampu mendukung entrepreneurial behavior seorang anak dan membangun intention dan karakteristik untuk menjadi entrepreneur.

Karakteristik yang ditemukan oleh Boz \& Ergeneli (2014) berkaitan dengan parenting style adalah creative, self-qualified dan independen. Berdasarkan tabel 2 dan tabel 3, creative dan independen merupakan dua kompetensi yang diharapkan ada dalam diri seorang entrepreneur. Penelitian Schmit-Rodermund (2004) di mana authoritative parenting style mampu memprediksi early entrepreneurial competence dalam diri seorang entrepreneur turut menguatkan kaitan antara authoritative parenting style dan entrepreneurial competence. Berdasarkan Rasmussen et.al (2011) kompetensi akan berkembang seiring pertumbuhan individu sehingga early entrepreneurial competence akan berkembang menjadi entrepreneurial competence yang dibutuhkan entrepreneur untuk menjadi entrepreneur yang sukses. Berdasarkan penelitian-penelitian tersebut maka disimpulkan bahwa authoritative parenting style terindikasi mampu memprediksi entrepreneurial competence yang dibutuhkan oleh seorang entrepreneur untuk meraih kesuksesan dalam pilihan kariernya menjadi entrepreneur.

\section{PROPOSITION DEVELOPMENT}

Hasil dari studi literatur di atas menemukan kerangka yang menjadi dasar bagi berkembangnya proposition di bawah ini.

1. Apakah Entrepreneurial Personality memiliki pengaruh terhadap Entrepreneurial Competence?

Berdasarkan kaitan yang diperoleh melalui studi literature ditemukan indikasi bahwa entrepreneurial personality memiliki pengaruh terhadap entrepreneurial competence, oleh karenanya peneliti mem-propose hubungan antar kedua variabel tersebut untuk dapat diuji lebih lanjut. Berdasarkan penelitian terdahulu oleh Schmitt-Rodermund (2004) yang didukung oleh penelitian obschonka et al. (2010), Obschonka et al. (2011) pengukuran entrepreneurial personality menggunakan teori big five personality, sementara peng- 
ukuran entrepreneurial competence menggunakan indikator yang diusulkan oleh Man \& Lau (2000) yang sesuai dengan model yang dikembangkan Frese (2009) dan diadaptasi oleh Brandstatter (2011).

2. Apakah Authoritative Parenting Style memiliki pengaruh terhadap Entrepreneurial Competence?

Authoritative parenting style diindikasikan memiliki pengaruh terhadap variabel entrepreneurial competence berdasarkan penelitian Schmitt-Rodermund (2004) di mana authoritative parenting style memengaruhi early entrepreneurial competence. Penelitian Rasmussen et al. (2011) menunjukkan bahwa kompetensi akan berkembang sesuai dengan perkembangan individu sehingga early entrepreneur- ial competence akan menjadi entrepreneurial competence saat individu dewasa dan menjadi entrepreneur. Hasil penelitian Tenibiaje (2010), Boz \& Ergeneli (2014) menguatkan indikasi tersebut sehingga peneliti mem-propose untuk dilakukan uji lebih lanjut hubungan antara kedua variabel ini.

Berdasarkan studi literatur yang dilakukan maka model yang diusulkan oleh peneliti untuk diujikan berkaitan dengan variabel entrepreneurial personality, authoritative parenting style, dan entrepreneurial competence dapat dilihat di Gambar 4 yang menunjukkan bahwa entrepreneurial personality dan entrepreneurial competence memiliki unobserved indicator sehingga peneliti mengusulkan pengujian menggunakan pendekatan structural equation modeling (SEM).

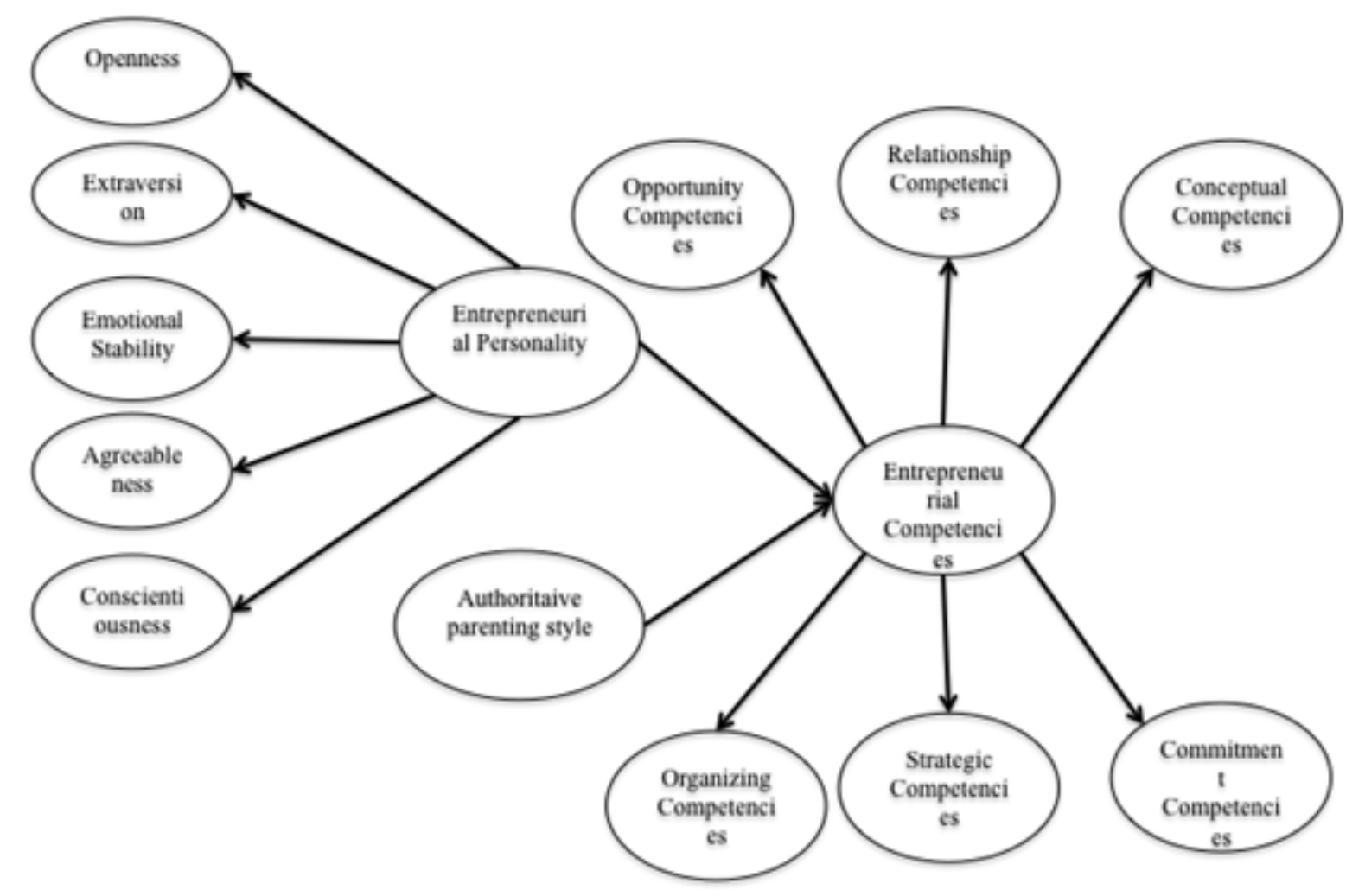

Gambar 4 Proposition Development Model: Entrepreneurial Personality, Authoritative Parenting Style dan Entrepreneurial Competence

Sumber: Data diolah (2018) 


\section{SIMPULAN DAN PENELITIAN SELANJUT- NYA}

Berdasarkan studi literatur yang dilakukan, ditemukan indikasi bahwa entrepreneurial competence diprediksi dipengaruhi oleh entrepreneurial personality dan authoritative parenting style. Indikasi tersebut muncul dikarenakan penelitian sebelumnya menunjukkan karakteristik yang dibutuhkan untuk menjadi entrepreneur yang memiliki kesamaan dengan indikator dari entrepreneurial competence. Penelitian-penelitian terdahulu juga menunjukkan bahwa entrepreneurial personality dan authoritative parenting style berpengaruh terhadap early entrepreneurial competence. Early entrepreneurial competence merupakan entrepreneurial competence yang dimiliki saat individu masih remaja dan akan berkembang seturut perkembangan individu tersebut. Berdasarkan studi literatur tersebut maka dapat disimpulkan bahwa pada dasarnya entrepreneurial personality dan authoritative parenting style mungkin berpengaruh terhadap entrepreneurial competence.

Berdasarkan proposition development yang dikembangkan dalam penelitian ini, penelitian selanjutnya yang akan dilakukan adalah menguji model yang diusulkan tersebut. Pengujian dilakukan untuk memvalidasi temuan dari hasil studi literatur dalam penelitian ini. Penelitian lebih dalam mengenai pengaruh parenting style lain terhadap entrepreneurial competence juga perlu dilakukan dikarenakan usulan parenting style mampu memprediksi entrepreneurial competence masih sedikit yang meneliti lebih lanjut.

\section{DAFTAR PUSTAKA}

Ahmad, N., Ramayah, T., Wilson, C., \& Kummerow, L. 2015. Is Entrepreneurial Competency and Business Success Rela- tionship Contingent upon Business Environment. International Journal of Entrepreneurial Behavior \& Research, 182-203. Amoros, J.E., \& Bosma, N. 2014. Global Entrepreneurship Monitor 2013 Global Report. Global Entrepreneurship Research Association.

Barron, L.G., Randall, J.G., Trent, J.D., Johnson, J.F., \& Villado, A.J. 2017. Big Five Traits: Predictors of Retesting Propensity and Score Improvement. International Journal of Selection and Assessment, 25, 138-148.

Baum, J.R., \& Locke, E.A. 2004. The Relationship of Entrepreneurial Traits, Skill and Motivation to Subsequent Venture Growth. Journal of Applied Psychology, 89 (4), 587-598.

Brandstatter, H. 2011. Personality aspects of entrepreneurship: A look at five metaanalyses. Personality and Individual Differences, 222-230.

Boz, A., \& Ergeneli, A. 2014. Women Entrepreneurs' Personality Characteristics and Parents' Parenting Style Profile in Turkey. Social and Behavioral Science, 109, 9297.

Capaldo, G., Iandoli, L., \& Ponsiglione, C. 2004. Entrepreneurial Competencies and Training Needs of Small Firms: A Methodological Approach. 14th Annual Intent Conference. University of Napoli Federico II.

Ishak, Z., Suet, F., \& Poh, L. 2012. Parenting Style as Moderator for Students' Academic Achievement. Journal of Science Education and Technology, 21 (4), 487493.

Garcia, F., \& Gracia, E. 2009. Is Always Authoritative the Optimum Parenting Style? Evidence from Spanish Family. Adolescence, 101-131. 
Jiang, D.S., Hayward, S.D., \& Morris, M.L. 2017. Raising Entrepreneurs: Can Parenting Style Amplify Entrepreneurial Intentions and Behaviours? International Journal management and Enterprise Development, 16.

Khalid, S., \& Bhatti, K. 2015. Entrepreneurial competence in managing partnerships and partnership knowledge exchange: Impact on performance differences in export expansion stages. Journal of World Business, $1-11$.

Man, T.Y., \& Lau, T. 2000. Entrepreneurial Competencies of SME Owner/Managers In The Hongkong Services Sector: A Qualitative Analysis. Journal of Enterprising Culture, 235-254.

Man, T.W., Lau, T., \& Snape, E. 2008. Entrepreneurial competencies and the performance of small and medium enterprises: an investigation through a framework of competitiveness. Journal of Small Business and Entrepreneurship.

Mitchelmore, S., \& Rowley, J. 2010. Entrepreneur Competencies: A Literature Review and Development Agenda. International Journal of Entrepreneurial Behavior o Research, 92-111.

Obschonka, M., Silbereisen, R.K., \& SchmittRodermund, E. 2010. Entrepreneurial Intention as Developmental Outcome. Journal of Vocational Behavior, 63-72.

Obschonka, M., Silbereisen, R.K., SchmittRodermund, E., \& Stuetzer, M. 2011. Nascent Entrepreneurship and the Developing Individual: Early Entrepreneurial Competence in Adolescence and Venture Creation Success during the Career. Journal of Vocational Behavior, 121-133.
Obschonka, M., Silbereisen, R.K., \& SchmittRodermund, E. 2012. Explaining Entrepreneurial Behaviour: Dispositional Personality Traits, Growth of Personal Entrepreneurial Resources and Business Idea Generation. The Career Development Quaterly, 60 (2), 178-190.

Papalia, D.E., Olds, S.W., \& Feldman, R.D. 2003. Human Development (Vol. 9th Edition). New York: McGraw-Hill.

Rasmussen, E., Mosey, S., \& Wright, M. 2011. The Evolution of Entrepreneurial Competencies: A longitudinal Study of Spin-Off Venture Emergence. Journal of Management Studies , 48 (6), 1314-1344.

Rauch, A., \& Frese, M. 2000. Psychological approaches to entrepreneurial success: A general model and an overview of findings. International Review of Industrial and Organizational Psychology, 101-142.

RezaeiZadeh, M., Hoga, M., O’Reilly, J., Cunningham, J., \& Murphy, E. 2016. Core Entrepreneurial Competencies and their Interdependencies: Insights from a Study of Irish and Iranian Entrepreneurs, University Students and Academics. International Entrepreneurship and Management Journal, 1-39.

Rocha, H., \& Birkinshaw, J. 2007. Entrepreneurship Safari: A Phenomenon-Driven Search for Meaning. In H.O. Rocha, D.B. Audretsch, \& J. Birkinshaw, Concepts of Entrepreneurship (pp. 1-35). Northampton, MA, USA: Edward Elgar Publishing, Inc.

Sanchez, J.C. 2013. The Impact of an Entrepreneurship Education Program on Entrepreneurial Competencies and Intention. Journal of Small Business Management, 51 (3), 447-465. 
Scherer, R.F., Adams, J.S., Carley, S.S., \& Wiebe, F.A. 1989, April 1. Role Model Performance Effects on Development of Entrepreneurial Career Performance. Entrepreneurship Theory and Practice.

Schmitt-Rodermund, E. 2004. Pathways to Successful Entrepreneurship: Parenting, Personality, Early Entrepreneurial Competence, and Interests. Journal of Vocational Behavior, 498-518.

Schutte, D. 2013. Toward a Competency Framework for SME Accountant- A South African Perspective. Global Journal of Management and Business Research Accounting and Auditing, 13 (5), 14-23.

Shute, V.J., Hansen, E.G., Underwood, J.S., \& Razzouk, R. 2011. A Review of the Relationship between Parental Involvement and Secondary School Students' Academic Achievement. Educational Research International, 1-10.
Sovet, L., \& Metz, A.J. 2014. Parenting Styles and Career Decision-Making among French and Korean Adolescents. Journal of Vocational Behavioral, 345-356.

Tehseen, S., \& Ramayah, T. 2015. Entrepreneurial Competencies and SMEs Business Success: The Contingent Role of External Integration. Mediterranean Journal of Social Sciences, 6 (1), 50-61.

Tenibiaje, D.J. 2010. Personality Traits, Parenting and Interest are Precursors to Successful Entrepreneurial Skills. Journal of Emerging Trends in Educational Research and Policies Studies, 25-28.

Volery, T., Mueller, S., \& von Siemens, B. 2013, February. Entrepreneur Ambidexterity: A Study of Entrepreneur Behaviours and Competencies in Growth-Oriented Small and Medium-Sized Enterprises. International Small Business Journal, 1-21. 
Accounting and Management Journal, Vol. 2, No. 1, July 2018 